\title{
Alexander Hamilton and Woodrow Wilson on the Spirit and Form of $a$ Responsible Republican Government
}

\section{David E. Marion}

Even a cursory review of contemporary scholarship on the presidency and the federal administration reveals a resurgence of interest in the political thought of Alexander Hamilton and Woodrow Wilson. Developments in the last decade involving the apparent enlargement of the authority and prerogatives of the national executive together with the popularization of the idea of an emerging American bureaucratic state have contributed to this renewal of interest in the work of both theorists. What is especially striking is that to a considerable extent the contemporary interest in the thought of Hamilton, and to a lesser but still significant degree in the political teaching of Woodrow Wilson, is rooted in the crystallization of opinion that is critical of the alleged predominance of the executive establishment and the appearance of an "imperial" presidency on the one hand, and the systematic interference of federal administration in the affairs of the people on the other. Thus, for example, a major theme in both the popular and academic press during the period of American history bracketed by the Vietnam War and the Watergate crisis centered on the illiberalism of a powerful executive. More recently, proponents of participationist democracy, particularly the devotees of the public interest advocacy movement and the selfstyled Tocquevillians of the public choice school, have urged reforms to check the concentration of power in the central government in general, and the national executive in particular. More importantly for the purposes of this essay, alongside this indictment of the national government has emerged an increasing tendency to cast Hamilton, witness the work of James McGregor Burns, and Wilson, a frequent target of criticism in the writings of that wing of the public choice school which includes Vincent Ostrom, as the theoreticians of a centralized executive-administrative order. ${ }^{1}$

${ }^{1}$ Burns casts Hamilton as the expositor of "presidential government" or a political order in which the executive "would act vigorously and creatively, dominating the legislative process as well as the executive, upsetting the carefully contrived balance of powers between nation and states and between President and the other branches" (James 
For his part, Hamilton is accused of advancing the virtues of a monocratic executive. It is the Hamiltonian model of the executive that is singled out as the historical paradigm for such reforms as the plan for an "administrative presidency" that was adopted by the Nixon White House. ${ }^{2}$ More generally, Hamilton's endorsement of an energetic executive and a strong national administration is cited as evidence of his impatience with democratic constitutionalism. Ostrom's critique of Wilson is cut out of the same fabric, with the principal attention being devoted to Wilson's defense of a politically neutral bureaucracy and an executive freed from the restrictions associated with the separation of powers doctrine. Wilson is variously charged with failing both to appreciate how easily his model for a professional administration would spawn an insensitive and domineering bureaucracy and to recognize the virtues of a system of separated and divided powers in a liberal constitutional republic. ${ }^{3}$ Underlying much of the criticism of Hamilton and Wilson is the perennial American suspicion of government. This attitude is reflected in the insistence that public agencies and their officers ought to be responsive to the popular will, constantly subject to public scrutiny, and should exercise authority only within a restrictive legal framework. Witness the study submitted to the Senate Committee on Watergate by the National Academy of Public Administration regarding the incompatibility of Nixon's plan for the "administrative presidency" with the nature and ends of democratic government. The NAPA report endorsed the idea of a "pluralistic" executive order and urged the extension of legislation such as the Hatch Act to politically neutralize more executive department personnel. ${ }^{4}$

MacGregor Burns, Presidential Government: The Crucible of Leadership [Boston, 1965], p. 18). Perhaps the most fully developed critique of Wilson in the public choice literature appears in Vincent Ostrom, The Intellectual Crisis in American Public Administration (University of Alabama Press, 1974), pp. 23-29.

${ }^{2}$ Consider in this connection, Richard P. Nathan, The Plot That Failed: Nixon and the Administrative Presidency (New York, 1975), p. 91. Also see Jacob Cooke, "The Hamiltonian Presidency: A Model for Our Time?" (Paper delivered at the White Miller Burkett Center, University of Virginia, 4 April 1978).

${ }^{3}$ In this regard, see especially Ostrom, Intellectual Crisis in American Public Administration, pp. 23-29; and Robert Bish and Vincent Ostrom, Understanding Urban Government (Washington, D.C., 1973), p. 8.

4 Frederick Mosher et al., Watergate: Implications for Responsible Government (New York, 1974), p. 51. Compare the reasoning of the NAPA Commission with the argument in favor of confining executive authority in order to preserve the strict separation of powers that appears in the concurring opinion submitted by Justice Douglas in the Steel Seizure case, Youngstown Steel and Tube v. Sawyer, 1952. 
What is commonly overlooked in much of the recent literature that is critical of a strong executive-administrative order, however, are the contrasting teachings presented by Hamilton and Wilson. This difficulty is indicative of a failure to probe the substantive basis of their respective defenses of a strong executive. As will become apparent, this sin of omission is especially glaring in Ostrom's work. In fact to telescope ahead momentarily, Wilson actually presented his political thought as a radical modification of Hamilton's vision of a decent and defensible republican government. It is the thesis of this essay that the current indictment of Hamilton, and the related critique of Wilson by Ostrom and others, can be traced largely to the understanding of "good" government that Wilson championed. If we abstract from the formal institutional dimensions of Wilson's idea of the defensible modern republic, what appears is a substantive commitment to the efficient implementation of the national popular will. More precisely, informing Wilson's work is the conviction that the democratic-egalitarian principles of the American regime are the fundamental and defining principles of the political order. But this is also the critical proposition that underlies many of the recent petitions for confining the prerogatives and discretionary authority of executive department officers. In short, Wilson's proposed "democratization" of the constitutional order is connected substantively to the recent critiques of both Hamilton and the strong executive and national system of administration with which he is traditionally associated. Thus, for example, both public choice theory and the public interest advocacy movement celebrate the sovereignty of the citizen-consumer at the expense of the authority and prerogatives of federal lawmakers and administrators. Accordingly, the study of the nature of the transformation of Hamilton's teaching occasioned by the political thought of Wilson should uncover the motives and significance of the principal rival opinions regarding the proper spirit and form of a responsible republican executive and administration. This exercise, in turn, should establish a basis for evaluating the merits of contemporary critiques of both Hamilton and Wilson as well as the adequacy of their thought as a defense of constitutional republicanism. Finally, such a study should heighten our understanding of the appropriate place and role of the national executive and administration within the American constitutional framework. 


\section{Hamilton's Idea of Responsible Republican Government}

It is perhaps to reverse the conventional wisdom on Hamilton to observe that what is frequently lost from sight is the connection in his thought between the energetic executive and defensible republican government. The Jeffersonian charge that Hamilton was a monocrat at heart has not only had a powerful effect on popular attitudes, but seemingly has obscured, and dampened interest in, Hamilton's republican credentials. In point of fact, both in his contribution to The Federalist Papers and elsewhere in his correspondence Hamilton acknowledges that what distinguishes and, indeed, recommends modern republican government is its rootage in the popular will. By its nature, the modern liberal republic rests on the elevation of the public will as the sovereign principle of governance. But just the proposition that popular consent supplies political legitimacy and forms the irreducible core of liberal republicanism was not contested by Hamilton. The following passage from a speech he delivered at the New York Ratifying Convention demonstrates that Hamilton had no quarrel with the republican principle of rule based on consent that figures prominently in the Declaration of Independence:

All governments, even the most despotic, depend, in a great degree, on opinion. In free republics, it is most peculiarly the case: In these, the will of the people makes the essential principle of the government; and the laws which control the community, receive their tone and spirit from the public wishes. ${ }^{5}$

Hamilton clearly understands the essence of republican government. Like John Marshall, Hamilton's endorsement of republicanism is based on the recognition that underlying the dependence of modern republican government on popular consent is a commitment to the preeminence of individual rights and the safety and happiness of the people among the ends of legitimate government. Significantly, it is as a self-proclaimed friend of liberty and defender of the security and prosperity of the people that Hamilton praises the virtues of a competent and effective national republican state. ${ }^{6}$

\footnotetext{
${ }^{5}$ Alexander Hamilton, The Papers of Alexander Hamilton, ed. Harold C. Syrett, 26 vols. (New York, 1960-78), 5:37 (hereafter cited as Papers).

6 In a letter to Lafayette, dated 6 October 1789 , Hamilton declares himself to be "a friend to mankind and to liberty" (Hamilton, Papers, 5:425).
} 
But Hamilton understands well that the virtues which recommend republican government may easily be neutralized by the characteristic problem that marks all popular regimes. In a capsule statement, the modern republic is plagued by the constant probability that the people will not recognize or embrace "right" opinion, understood as opinion that promotes the safety and prosperity and secures the liberties of the people. This is the characteristic problem of republican government precisely because of the rootage of republican systems in the popular will. It is also the problem that calls the strong republican executive into being. As a species of popular government, a democratic republic is at its best when informed by enlightened public opinion or the deliberate will of the community. Especially at the founding, but not confined to the formative period, the presence of "right" opinion in the citizen body is crucial. Unless it is to be left to accident or chance, the choice of a decent and defensible republican system depends on informed deliberation by the citizen body. That this was not lost on Hamilton is evident from the significance attached by him to convincing the people through reasoned arguments of the utility of the Constitution, and the strong national executive promised by the Constitution, to the ends of a liberal and prosperous civil society. This was the task undertaken in The Federalist Papers. But what bears emphasizing, mainly because it is frequently lost from sight, is Hamilton's acknowledgment that a government can be republican only so long as its principal guide is the public will; while it can be a decent and defensible republic only as long as the public will is informed. Thus as a friend of republican government, Hamilton is obliged to promote "right" public opinion. It is also the impossibility of guaranteeing the dominance of "right" opinion that renders the strong executive necessary according to Hamilton. That is to say, his defense of the energetic executive in only intelligible in light of the centrality of "right" opinion to "good" government.

To repeat, however, precisely because republican government rests on the principle of popular consent it is peculiarly vulnerable to faltering whenever the people fail to appreciate the demands of the common good. It was with the intent of compelling the people to consider their best interests and, thus, to make republican government equal to its ends that Hamilton endeavors in The Federalist to instruct the popular will as he was later to instruct the 
legislative will in his reports as secretary of the treasury. ${ }^{7}$ To succeed in this exercise Hamilton recognizes that appeals must be made to the interests of the people. More precisely, the desideratum is to confront the people on the level of their interest with reasoned arguments. Such a policy, however, is not by its nature evidence of a lack of faith in democratic republicanism. This exercise, when undertaken seriously, clearly requires that you have some faith in the capacity of the people for reflection on the true nature of their interests. In fact, Hamilton recognizes that republican government, more than any other political system, presumes the presence of self-discipline and a capacity to form judgments based on enlightened self-interest in the citizen body. Hamilton's defense of the American constitutional republic is evidence of a belief that there is more knowledge and decency in the people than ignorance and perversity.

Hamilton's faith in the capacity of men to respond to reasoned arguments appealing to their best interests translates into the conviction that democratic government can be decent and defensible. But experience reveals that not all persons will be equally open to such arguments. Hence, Hamilton's specific appeal in The Federalist for the support of the unprejudiced and the sincere friends of liberty for the energetic executive. ${ }^{8}$ Appeals to the interests of such citizens through reasoned arguments are most likely to prompt judgments based on a due regard for the security of private rights and the advancement of the general welfare. By contrast, the best that can be done in the case of persons given to unreflective or impractical views and prejudiced political opinions is to diminish their influence on the citizen body. Accordingly, in the case of the most prejudiced critics of the Constitution, Hamilton can expect to quiet them at-best, and must dull their effect on the general public at the least. This is the crux of his position with respect to the critics of the strong executive. Hamilton's strategy is to address those persons whose opposition to a strong central government and energetic executive is based less on a commitment to the moral and public virtues than on the protection of private rights. With persons of this persuasion, Hamilton can make a convincing defense of the Constitution in terms of

7 See, for example, the opening paragraphs of the report on the national bank (Hamilton, Papers, 7:256-57).

${ }^{8}$ Hamilton, Madison and Jay, The Federalist Papers (New York, 1961), No. 23, p. 153: also No. 36 , p. 224 ; No. 61 , p. 372 : and No. 85. 
security and prosperity.

Not surprisingly, the most controversial elements in Hamilton's vision of a defensible republican system are connected to the probability that appeals even to the best interests of most of the people will not always be successful in generating "right" opinion. Here is the rub and the basis of Hamilton's defense of a strong national government. This, in turn, has spawned the accusation that Hamilton preferred an "aristocratic" republic to one that was democratic in nature. ${ }^{9}$ It is, in fact, the constant probability that popular opinion will not coincide with the best national interest that leads Hamilton to attach considerable importance to devices that enable the government to refine and moderate, and indeed to check when necessary, popular opinion. It is to meet the demands of the common good when the citizen body does not recognize its best interest that Hamilton proposes the strong and independent executive armed with a capable administration. As Hamilton demonstrates in Federalist, No. 71, implicit in the trust with which the president is charged is a responsibility to discriminate between informed and uninformed public opinion:

The republican principle demands that the deliberate sense of the community should govern the conduct of those to whom they intrust the management of their affairs; but it does not require an unqualified complaisance to every sudden breeze of passion, or to every transient impulse which the people may receive from the arts of men, who flatter their prejudices to betray their interests . . . When occasions present themselves in which the interests of the people are at variance with their inclinations, it is the duty of the persons whom they have appointed to be the guardians of those interests to withstand the temporary delusion in order to give them time and opportunity for more cool and sedate reflections. ${ }^{10}$

Now without doubt, Hamilton's energetic executive is the most distinctive ingredient in his conception of "good" government or moderated democratic government, that is, a popular government committed to securing the private rights and pro-

${ }^{9}$ An early example of this opinion appears in the generally insightful volume by Henry Cabot Lodge on the life of Hamilton: "He believed in class influence and representation, in strong government, and in what, for want of a better phrase, may be called an aristocratic republic" (Henry Cabot Lodge, Alexander Hamilton [Boston, 1898], p. 278; also see p. 138).

10 Hamilton, Federalist, No. 71, p. 432. Also consider Alexis de Tocqueville, Democracy in America, trans. George Lawrence (New York, 1969), p. 223. 
moting the comfortable preservation of the citizen body. For Hamilton, a strong executive is a "leading character" in the definition of "good" government." The energetic executive enables republican government to be equal to the ends of "good" government in the sense of providing the capacity for decisive action necessary to all government and the wherewithal to adjust the competition of rival rights and interests in a democratic system where men are least habituated to accept restraints and most disposed to press their claims. It is this view of the necessity for a strong executive that compels his response in Federalist, Nos. 68 and 70 , to the proposition that a vigorous executive is inconsistent with republican government. If this proposition is correct, or if the people are led to believe that it is correct, then republican government will be ill prepared to satisfy the requirements of "good" government. This theme is bluntly addressed in Federalist, No. 70, when Hamilton insists that a feeble executive is a bad executive and that such an executive invariably issues in bad government. ${ }^{12}$ Notice, however, that Hamilton never proclaims the energetic executive to be the necessary and sufficient cause of "good" government, only a "leading character" of "good" government. Still, he reserves his fiercest criticism for those persons who maintain that the strong executive is incompatible with republican government. If the critics of the strong executive succeed in persuading the people to weaken the vigor or independence of the president, they would effectively undermine an important device for moderating popular opinion and, accordingly, diminish the defensibility of the republican system in this nation.

Briefly summarized, Hamilton's commitment to an energetic executive is only intelligible in the context of his understanding of the purposes and the peculiar dangers of the modern republic. Rather than leave the safety and happiness of the people and the security of private rights to the chance that the people will embrace "right" opinion or that foreign threats will never demand the attention that prompted Locke to argue for entrusting "prerogative" powers to the executive, Hamilton recommends the inclusion in the formal constitutional order of "devices of prudence" for neutralizing the dangers to which republican governments are especially prone. This thought can be traced to

11 Hamilton, Federalist, No. 70, p. 423.

12 Ibid. 
an important dimension of the modern liberal tradition, that is, to the claim that government by consent means government by the consent of men who are enlightened about their rights and able to choose a government protective of those rights. Consider in this connection the fact that the American Constitution requires that amendments to the fundamental law be ratified or defeated by representative agencies of the people and not by the people directly. ${ }^{13}$ In keeping with this same principle, Hamilton's plan for a strong executive is intended to afford special protection for the decisive ends of republican government, that is, for the rights and safety, along with the happiness and prosperity of the people. The executive's veto and control over the administration are examples of devices that Hamilton understood would enable a president to guide public policy, and popular opinion generally. As Hamilton believed that a competent national administration could capture the allegiance of the people from the states, so he anticipated that an efficient administration of the affairs of the nation by the executive would strengthen his influence over the opinions and demands of the people. Clearly the premier example of such an executive was Washington. To summarize Hamilton's thoughts, by promoting government that is guided by the deliberate and informed will of the community, an energetic executive and an efficacious administration increase the likelihood that the republic will be equal to its own ends.

According to Hamilton, then, an executive capable of temporarily checking misguided popular or even legislative majorities, and able to avoid the temptation to serve the people's inclinations rather than their best interests, is an essential ingredient of a republican system that is preservative of the equal rights of all of its members. Admittedly, the emphasis must be on the temporary nature of the executive check. In a democratic republic, checks on the popular or legislative will by the president ought to be only such as will promote deliberation, not such as will fundamentally change the nature of the political system. Nor should it be forgotten in this regard that Hamilton's executive represents the national popular will at the pleasure of the people themselves. Hence in a fundamental respect Hamilton's treatment of the responsibilities of the republican executive preserves the distinction between "ruling" and "governing." Consider in this

${ }^{13}$ On this question, see the decision of the United States Supreme Court in Hanke v. Smith, 253 U.S. 21 (1920). 
context Hamilton's insistence that the single executive not only provides for decisiveness and vigor, but promotes accountability in government. ${ }^{14}$ In short, his is a model of institutionalized or confined and responsible leadership. The necessity to balance the strong executive with proper safeguards for the safety and liberty of the people was freely acknowledged by Hamilton at the time of the New York Ratifying Convention:

There are two objects in forming systems of government-Safety for the people, and energy in the administration. When these objects are united, the certain tendency of the system will be to the public welfare. If the latter object be neglected, the people's security will be as certainly sacrificed, as by disregarding the former. Good constitutions are formed upon a comparison of the liberty of the individual with the strength of government: if the tone of either be too high, the other will be weakened too much. ${ }^{15}$

Accordingly, the great claim that can be made on behalf of Hamilton's plan for the presidency is that it brings together the responsibilities of the national executive and the principles of constitutional republicanism. Hamilton's executive is not merely an instrumental device for the efficient administration of the affairs of state, but a formative agent intended to promote "right" public opinion without which the regime of liberty is impossible. What reappears in this conclusion is the earlier thesis that it is the centrality of "right" opinion to "good" government that renders the strong executive intelligible and defensible.

To understand Hamilton's executive it is necessary to appreciate his view of the nature and characteristic problems of democratic republics. In this connection it is instructive that he begins and ends his contribution to The Federalist Papers with appeals to good judgment and a prudent regard for what is possible. Hamilton recognized as well as any of the Founders that what is possible is far more modest than what might be desirable. What is possible is the establishment of a liberal republic that rests on the personal interests of the people and affords protection for their private rights. These are hardly the lofty and ennobling aims of classical political philosophy. Nor did these goals satisfy the desire on the part of some Anti-Federalists for securing the moral and

14 Hamilton, Federalist, No. 70, pp. 427-28.

15 Hamilton, Papers, 5: 81: also pp. 94-95. 
public virtues. But Hamilton is confident that the strong national government and energetic executive made possible by the Constitution would satisfy the expectations of men of good judgment who have a sensible appreciation of the advantages as well as the characteristic weaknesses of the modern republic and of the limits to what can be accomplished through political arrangements. ${ }^{16}$ To paraphrase Madison, the Constitution can survive examination by persons who recognize that men are not angels and that securing comfortable self-preservation in a regime of rights is hardly a negligible accomplishment. For Madison and Hamilton, the extended liberal republic could be expected to promote greater justice than the older orders and would be far easier to establish and maintain than the ideal regimes of antiquity. In short, Hamilton's political wisdom is marked by a fixed attention to the limits of political action. This "political realism" bore heavily on his conduct as a public servant and, more generally, as a.political thinker. His distrust of messianic philosophies and speculative reformers is nowhere better evidenced than in a letter addressed to the Marquis de Lafayette in the year of the Constitution's ratification: "I dread the reveries of your Philosophic politicians who appear in the moment to have great influence and who being mere speculatists may aim at more refinement than suits either with human nature or the composition of your Nation." ${ }^{17}$ It is Hamilton's appreciation of both the virtues and the weaknesses of the republican form that lies behind his insistence on the indispensability of the competent and energetic executive in the modern regime of rights.

\section{Wilson's Vision of Democratic Republicanism}

Needless to say, Hamilton's understanding of the requisites and ends of a defensible republican system has not gone unchallenged. The twentieth century has witnessed the emergence of a vision of democratic republican government that is rooted in governmental responsiveness and the elevations of the principle of equality to archetectonic status. This body of thought appears to have received its formative, and perhaps its most compelling, ex-

\footnotetext{
${ }^{16}$ During the New York Ratifying Convention Hamilton expressed confidence that "prudent men will consider the merits of the plan in connection with the circumstances of our country. .." (Hamilton, Papers, 5: 71).

17 Hamilton, Papers, 5:425.
} 
pression in the political teaching of Woodrow Wilson.

Not unlike the political thought of Hamilton, Wilson's political teaching is informed by a view of the requisites and purposes of republican government. As in the case of Hamilton, the quintessential form of "good" government for Wilson is a popular system that promotes competence and responsibility. Moreover, Wilson shared with Hamilton the conviction that responsible republican government requires the presence of certain ingredients, energy in the executive and competence in the national administration being among the most prominent ${ }^{18}$ In fact, Wilson's defense of just these qualities in the political system draws the criticism of persons who are suspicious of reforms that promote centralization and the erosion of the separation of powers in the national system. ${ }^{19}$ But in contrast to Hamilton, whose defense of the Constitution celebrates the moderating purposes of representative democracy, Wilson anticipates and justifies the contemporary plea for greater responsiveness on the part of public officials to popular demands. To paraphrase Herbert Croly, Wilson championed "the transformation of Hamiltonianism into a thoroughly democratic principle." ${ }^{20}$ In short, the democraticegalitarian face of the American political order pierces through the formal, institutional side of Wilson's model of democratic government, that is, that side of Wilson's thought which most resembles Hamilton's idea of a defensible republic.

The contrast between Hamilton's understanding of the purposes and nature of "good" republican government and the democratic-populist and progressive impulses of the late nineteenth and early twentieth centuries did not go unheeded by

${ }^{18}$ Wilson's thoughts in this regard are reflected in the following passage: "A democracy, by reason of the very multitude of its voters and their infinite variety in capacity, environment, information, and circumstance, is peculiarly dependent upon its leaders. The real test of its excellence as a form of government is the training, the opportunities, the authority, the rewards which its constitutional arrangements afford those who seek to lead it faithfully and well. It does not get the full profit of its own characteristic principles and ideals unless it uses the best men in it, without regard to their blood or breeding. It cannot use them unless it calls them into service by adequate rewards of greatness and power. Its problem is to control its leaders and yet not hamper or humiliate them; to make them its servants and yet give them leave to be masters too, not in name merely but in fact, of the policy of a great nation-types of a power that comes by genius and not by favor" (Woodrow Wilson, The Papers of Woodrow Wilson, ed. Arthur S. Link [Princeton, 1966-] 12: pp. 178-79) (hereafter cited as Wilson Papers).

${ }_{19}$ See Ostrom, Intellectual Crisis in American Public Administration, especially pp. 23-29: Bish and Ostrom, Understanding Urban Government, especially p. 8.

20 Herbert Croly, The Promise of American Life (New York, 1963), p. 153. 
Wilson. Indeed, his work proclaims the emergence of a new period in the political life of the country. In his preface to The New Freedom, Wilson speaks of the "New Spirit" of American politics and heralds a revolution aimed at "modernizing" and invigorating the United States. ${ }^{21}$ There is little doubt that Wilson sought to become active in shaping that revolution. ${ }^{22}$ Now in order to consummate this transformation of the political order, he announced that the debate over constitutional principles must give way to the practical demands of improving the quality of life of the "common man." That is to say, the premier chore is to improve the general welfare in the most expansive sense of the phrase. For Wilson, promoting a decent life for all Americans constituted the "new" national purpose, on whose behalf the entire machinery of the central government is to be mobilized.

According to this reasoning, then, the American political order needed to be brought in stride with the spirit of modernity. When Wilson authored his first important works in political science and public administration he considered the United States to be in a new phase of its development and the Western nations in general to have entered a significant period of their history. In keeping with the progressive creed, Wilson insisted that the late nineteenth century was marked by the advance of democratic principles and practices. Especially prominent in this regard is his faith in the progressive enlightenment of popular opinion. It is this faith in the course of historical enlightenment that spawns his confidence that the "common man" can reasonably be invited to participate in shaping the political life of the country. This, in fact, is the dominant theme of The New Freedom. Wilson did not equivocate in this regard, as is evident from his declaration that, "the deepest conviction and passion of my heart is that the common people, by which I mean all of us, are to be absolutely trusted." ${ }^{23}$ Conceding that the people are sometimes indisposed to act, he nevertheless proclaims himself to be "among those who believe so firmly in the essential doctrines of democracy that I am willing to wait on the convenience of this great sovereign [the people], provided I know that he has got the instrument to dominate

21 Woodrow Wilson, The New Freedom (New York, 1919), Preface.

22 Herbert Croly announced shortly after the turn of the century that "reconstruction" and not simple "restoration" was the order of the day (Croly, Promise of American Life, p. 152).

23 Wilson, New Freedom, p. 109. 
whenever he chooses to grasp it."24 This conviction is underscored by the statement that appears in his 1887 essay on the study of administration that the popular will constitutes "the motive force of government." 25 The popular will is treated by Wilson as the fundamental determinant of the character of the political community. Hence the significance he attaches to transforming the popular will into law. Democracy, the characteristic modern regime for Wilson, is distinguished by its commitment to transforming the will of the people into the law of the community. To borrow directly from Wilson, the laws should be attuned to the "common judgment." 26 As the crystallization of the popular will, law for Wilson is the "determinate will of the State" regarding the ends or purposes to which the community has committed itself. ${ }^{27}$ To put this differently, and perhaps in a more revealing context, the "nature" of the state appears in its laws. ${ }^{28}$ By implication, if the "nature" of the state appears in the public laws, and the laws reflect a fluctuating or indeterminate public will, then the "nature" of the state is malleable and historical rather than fixed and permanent. Just this historicism underlies Wilson's plea for a responsible, understood principally as a responsive, legislature. Devices for the efficient implementation of the popular will, the most prominent in his work being party government and a system of administration based on the principles of administrative science, eclipse in importance constitutional principles. The idea that the "nature" of the state appears in fixed or permanent principles recedes from attention. ${ }^{29}$ What becomes important is the capacity of the political order to adjust to the shifting character of American attitudes and preferences. Here is the basis for his declaration that the laws of the country should "reflect historical habit and the development of the nation." 30 To put this differently, that government is "good" which is "amenable from day to day to public opinion," and capable of redefining its purposes to accommodate changing values. ${ }^{31}$ Just this reasoning underlies

24 Ibid., p. 231.

25 Woodrow Wilson, "The Study of Administration," Political Science Quatterly (1887), p. 216.

26 Wilson Papers, 6: 286: also see p. 279.

27 Ibid., p. 286.

28 Ibid., p. 266: also 8: 37.

${ }^{29}$ Ibid., 6: p. 286, 279.

30 Ibid., p. 275.

31 Ibid., 4: 62. 
Wilson's critique of the prevailing practices and general character of the American legislative process.

Among the controversial themes in Wilson's work is the allegation that democracy in the United States had been tarnished by irresponsible governance and administration. ${ }^{32}$ This criticism takes two forms: first, the charge that public policies typically subordinate majority interests to factional interests and, hence, distort and frustrate the popular will; and, second, the declaration that the public policy process is inefficient and unbusinesslike, and results in the ineffective use of public authority and resources to advance the general welfare. This two-pronged criticism points towards the view that government, to be decent and defensible, must contribute to the efficient implementation of the national popular will. For Wilson, then, the test of "good" government is decidedly the capacity of the political order to respond to prevailing social forces, rather than to entrenched interests or permanent constitutional principles - a view of democratic government that appears in the legal scholarship of Justice Oliver Wendell Holmes during this same period. From this thought issues Wilson's defense of a strict party system, consolidated government, and a more businesslike system of administration. Wilson, it is profitable to recall, is best remembered for his defense of cabinet or party government. ${ }^{33} \mathrm{He}$ championed a system that would permit the people to decide between distinct parties whose officials could be held responsible for the programs and conduct of party members; while the leaders of the majority party might be held accountable for the actions of the government. ${ }^{34}$ His thoughts on this subject are well preserved in the following passage from Congressional Government:

It should be desired that parties act in distinct organizations, in accordance with avowed principles, under easily recognized leaders, in order that the voters might be able to declare by their ballots, not only their condemnation of any past policy, by withdrawing all support from the party responsible for it; but also and particularly their will as to the future administration of the government, by bringing into power a party pledged to the adoption of an acceptable policy. ${ }^{35}$

For Wilson, responsible, disciplined, programmatically distinct

\footnotetext{
32 Ibid., 12: 9 and 4: 141 .

33 Ibid., 8: 269; and 5: 122.

34 Ibid., 5: 332, 53.

35 Ibid., 4: 62.
} 
parties competing for public favor constitute the best conduits of the majority opinion in governmental affairs; while a system of administration guided by the principles of administrative science is represented as the most effective arrangement for adjusting public policies to satisfy majority wishes.

Significantly, it is this elevation of the majority will in terms of governance, together with Wilson's confidence in the progressive enlightenment of popular opinion, that lies behind his projection of administrative activities to a place closer to the center of governance. In his essay on administration he unreservedly submits that the students of the science of administration will know best how to secure the goals desired by the "common people." 36 But what is particularly noteworthy is that Wilson rests the claim of the new class of professional administrators to participate in governance on their knowledge of the means most adapted to the objectives desired by the citizen body and reflected in their support of programmatically distinct parties. Thus the conclusion that while public opinion should not become "meddlesome" in administration, it ought to remain the "authoritative critic" of administrative decisions. ${ }^{37}$ Indeed, although Wilson appears to stake out a separate and significant place for administrators in the policy process, seemingly including the task of educating public opinion, he provides no substantive basis on which to rest and defend such activity in the administrative domain. ${ }^{38}$ In urging the need for the mastery of administrative science, Wilson suggests in his 1887 essay that an administration free to act in the policy process is acceptable as long as it serves the national interest. At the same time, however, his historicist faith in the increasing enlightenment of popular opinion entrusts the definition of the national interest to the people. Wilson's historicism contains no substantive principle that would prevent public opinion from meddling with administrative subjects. If the dominant view of Wilson's endorsement of the politics-administration dichotomy unfairly ascribes to him the naive belief that administration can legitimately be separated from policy matters, it nonetheless accurately reflects the absence of a substantive basis in his thought for the guidance of public policy by administrators. His thoughts on administration and party politics celebrate the rule of the

\footnotetext{
36 Wilson, "The Study of Administration," pp. 214-16.

37 Ibid., p. 214.

38 Ibid., p. 215.
} 
popular will and, especially, the importance of serving the goal of self-defined personal development on the part of the "common people." By comparison with Hamilton, the Wilsonian scheme renders suspect, even though it does not explicitly reject, all checks on the popular will.

It is in the context of Wilson's broadest political teaching that we can understand, despite their agreement on the necessity of an efficient system of administration and a strong executive, why he describes Hamilton as a "great man, but . . . not a great American." 39 This judgment is based on Hamilton's reservations about adjusting governmental policies to coincide with the opinions and interests of Wilson's "common man." For Hamilton, the opinions and interests of the "common man" ought to be made to coincide with a republican system that recognizes the dangers of allowing uninformed or illiberal opinion to rule. Informing this position is the understanding that not all opinions are salutary or even tolerable. According to Hamilton, interests and opinions should not be permitted to roam at will, but ought to be guided to promote the best national interest. Thus his political thought points to the necessity for leadership that is formative in nature, that is, to an arrangement of republican government that gives the officers the necessary motives and constitutional powers to instruct popular opinion and, when necessary, to check the popular will. By contrast, the crucial problems for Wilson are instrumental or functional in nature. That is to say, Wilson devotes his work to reforms that will improve the capacity of the political order to respond to the national popular will. Here, indeed, is for Wilson the litmus test of the democratic bona fides of the political system. To summarize, whereas Wilson devotes considerable attention to the instrumental or ministerial side of democratic government, witness his celebration of the virtues of the science of administration, Hamilton counsels attention to the formative side of republican government, and especially to the hospitality of the political system of leadership, if not statesmanship.

The consequences of these competing positions are no less politically significant than they are academically interesting. As a result of the concessions that Wilson makes to popular majority opinion, his political thought provides little substantive guidance for responding to petitions for reforms that would confine the na-

39 Wilson, New Freedom, p. 55. 
tional system of governance and administration in the name of advancing democratic liberties. To take a contemporary example, the democratic-egalitarian convictions that underlie Wilson's thought afford no appreciable resistance to the pleas of public interest advocacy groups which wish to strengthen the regulatory process through participatory rather than through formal governmental arrangements. The thrust of the public interest advocacy movement is to provide protection for "the public interest" by relying less on legislative or executive action or on the exercise of discretionary authority by professional administrators, and more on judicial processes that in principle assure an impartial hearing for aggrieved individuals and groups. This preference for "nonpartnership" and decision-making by the judicial forum emanates from a conviction that "political" activities are "partisan" in nature and, hence, inherently defective. To take a second example, Wilson's thought is equally hard-pressed to rebut public choice theorists like Vincent Ostrom who champion a revitalized federal system with a large measure of decentralization as the most efficient political arrangements for satisfying citizen-consumer preferences. Perhaps more ominous than the implications for sustaining a strong national government contained in the public choice model is the effect of the principle of consumer sovereignty on governmental practices. Clearly, the consequence of assigning the decisive control of political affairs to citizen preferences is to discourage judgments rooted in the distinction between enlightened or informed and unenlightened public wishes. Thus Ostrom's attempt to claim Hamilton as an ally of the public choice movement reflects a fundamental misunderstanding of his thought. Ostrom seemingly does not recognize that Wilson is substantively much closer to the public choice school than Hamilton. ${ }^{40}$ Having singled out the opinions or the "common people" as the controlling standard for guiding political action, Wilson fails to provide any substantive basis for challenging petitions raised on behalf of the sufficiency of unrefined public opinion. In fact, his thought lends itself to the sanctification of unrefined popular opinion. Wilson cannot adequately protect the for-

40 Compare Ostrom's understanding of Hamilton's political thought (Intellectual Crisis in American Public Administration, pp. 81-90) with Hamilton's own description of his objectives in Federalist, Nos. 1, 15, 23, 27, 34, and 59, and in his June 18th speech at the Philadelphia Convention (Max Farrand, ed., The Records of the Federal Convention, of 1787, 4 vols. [New Haven, 1966] 1: 282-311). 
mal, institutional side of his political teaching; that is, his defense of the strong president and a national administration based on the principles of administrative science, against the critiques of the public choice theorists and the public interest advocacy movement.

The petitions for replacing both traditional governmental procedures and the exercise of discretionary authority on the part of professional administrators by direct citizen participation in decision-making and a reliance on the judicial forum for regulating public and private sector activity not only signify lack of confidence in the motives and procedures of the national government, but, and more importantly, threaten to erode the basis for a strong and effective national system, such as Wilson considered indispensable to a decent democracy. Precisely because of the substantive features of his political philosophy, the institutional reforms counseled by Wilson have no defense against being held hostage to prevailing majority opinions or to the reforms championed by the public choice school. In point of fact, the institutional reforms recommended by Wilson are derivative from the principle that governance should be based on the satisfaction of majority preferences. This political thought can provide no firm basis for statesmanship as understood by a Lincoln. By contrast, Hamilton's political thought supplies a principle for continuing radical participatory democracy and for discriminating between informed and uninformed public opinion without eliminating necessary restraints on governmental activity of due process guarantees for individual rights.

The ease with which Wilson's political thought is confused with Hamilton's defense of a strong, centralized executiveadministrative order is revealing of the contemporary disregard for the substantive side of political thought and action. Indeed, it would appear that the majority of the critics of Hamilton's thought subscribe to the same historicist posture that underlies Wilson's work and are heirs to the same egalitarian preferences that inform Wilson's rhetoric. It has been the object of this article to demonstrate that we have in Hamilton's political thought and the public teaching of Woodrow Wilson contrasting visions of a decent and defensible republican order. The temptation to dismiss both Hamilton and Wilson, reflected substantively with respect to Hamilton and formally with respect to Wilson in the work of Ostrom, suggests a general failure to appreciate the 
precise nature of these separate sources of the modern American political community. Moreover, this practice places us in danger of failing to recognize the purposes and consequences of the principal alternative views of the proper nature of a democracy community. By returning to the political thought of Hamilton and Wilson we can deepen our understanding of the competing arguments on behalf of rule based on popular opinion in a system fashioned to promote the efficient implementation of the majority will, and rule based on the deliberate will of the community in a system intended to moderate and even check illiberal, unreasonable, or uninformed popular inclinations. The tension between these contrasting principles of governance marks the entire constitutional framework of the American regime. And, to be sure, our understanding of the principle of official responsibility that should govern the conduct of public officials will be decisively affected by the outcome of the competition between the Hamiltonian and Wilsonian views of the nature and purposes of a defensible modern republic, and between both of these positions and the recent critiques of a strong national government and vigorous executive that celebrate the democratic-egalitarian principles to which Wilson was committed. 